\title{
Then and now: a brief history of acta ethologica
}

\author{
Peter McGregor • Rui F. Oliveira
}

Published online: 4 March 2014

(C) Springer-Verlag Berlin Heidelberg and ISPA 2014

acta ethologica has seen some major changes in the recent months, so this seemed an appropriate time to look back on how the journal has developed from its beginnings as the official journal of the Portuguese Ethological Society (SPE), and also to look forward to what the journal could become.

acta ethologica was launched as the society journal of SPE back in 1998. SPE was established in 1987, and from the beginning, a main objective was the publication of a scientific journal in the field of animal behaviour. The goal was for this journal to publish original contributions in the field of ethology and related disciplines, with a special emphasis on studies integrating proximate (i.e. mechanisms, development) and ultimate (i.e. function, evolution) levels in the analysis of behaviour. During the 1970s and 1980s, ethology was facing conceptual challenges which led to the development of different research traditions in animal behaviour, with researchers focused on the study of proximate mechanisms of behaviour (neuroethology) on one side and those focused on the function of behaviours (behavioural ecology) on the other. So, the publication of a journal with a wide remit in the field could be seen as an effort to integrate these different levels of analysis of behaviour, as proposed by Tinbergen in his seminal 1963 paper on the methods and concepts of ethology. The founders of SPE, namely António Bracinha Vieira, Vitor Almada, Rodrigo Saraiva and Luis Vicente, among others, wanted the title of the journal to reflect this integrative essence

P. McGregor $(\square)$

Centre for Applied Zoology, Cornwall College Newquay, Wildflower Lane, Trenance Gardens, Newquay TR7 2LZ, UK

e-mail: peter.mcgregor@cornwall.ac.uk

R. F. Oliveira

ISPA-Instituto Universitário, Rua Jardim do Tabaco 34,

1149-041 Lisbon, Portugal

e-mail: ruiol@ispa.pt of the ethological approach to the study of animal behaviour. After considerable discussion, the title acta ethologica was chosen. Interestingly, the same title had been proposed for the new journal that Tinbergen himself launched after the Second World War to promote the development of ethology and to reestablish international collaborations in the field. However, W. $\mathrm{H}$. Thorpe, who was one of the co-editors, raised the concern that a Latin title would not attract the attention of English readers and the journal was ultimately called Behaviour (Burkhardt 2005). When we became aware of this story, it gave a new layer of meaning to the title as truly embedded in the integrative spirit of ethology.

SPE had limited financial resources, so an agreement for the publication of acta ethologica was established between SPE and Instituto Superior de Psicologia Aplicada (ISPA). ISPA is a university institute based in Lisbon and has the oldest School of Psychology in Portugal as well as a renowned publishing office in the field of behavioural and psychological sciences. Since ISPA was also the institution that had hosted SPE from its beginnings, the joint efforts for the publication of acta ethologica made all the more sense.

The first volume of acta ethologica was a double issue published in August 1998 with Rui Oliveira as chief editor. The journal was presented to the international community at the 1998 International Behavioural Ecology Congress held in Asilomar, California. Dieter Czeschlik, the Life Sciences Editor of Springer-Verlag, happened to be present at that meeting and a proposal for Springer to publish the title followed. Springer has published acta ethologica from the 2nd volume. In the following years the journal was consolidated as a new title in the field with an increasing numbers of manuscript submissions and a stable acceptance rate. It received its first impact factor in 2008. In 2005, the Spanish Ethological Society (SEE) joined the journal and appointed Juan Carlos Señar (Barcelona) to serve jointly as chief editor together with Rui Oliveira. 
In 2013, a number of major changes occurred, marking the start of a new era in the development of the journal. One major change has been SEE's decision to withdraw from the publishing agreement. Another has been Rui Oliveira's decision that 16 years as chief editor is enough. Rui has handed the position over to Peter McGregor, who has been an associate editor for 14 years. The third change is that three issues a year have been published from 2013, reflecting the increasing number of high quality submissions received by the journal.

It is clear that authors prefer a short time between submission and initial decision. Achieving this requires considerable commitment to the refereeing process from acta's peer reviewers and the associate editors (who identify suitable referees and make a publication recommendation based on the referees' reports). In an increasingly busy world, it is not easy for anyone to commit to rapidly turning around a manuscript. We are fortunate that our associate editors have made such a commitment and that they seek out referees who are similarly committed. This commitment, together with small improvements to the online manuscript handling system, will reduce the time from submission to initial decision. The addition of new associate editors has increased the international coverage of the editorial board. Although it is always difficult to equate changes that make academic sense with a corresponding increase in impact factor, we hope that these changes will help to increase the impact factor. In a nutshell, we are developing acta ethologica into a rapid turn-around, international journal dealing with a wide range of taxa and maintaining the integrative essence of the ethological approach to the study of animal behaviour enshrined in the title.

Rui Oliveira

Peter McGregor

Feb 2014

\section{References}

Burkhardt R.W. (2005). Patterns of behavior: Konrad Lorenz, Niko Tinbergen, and the Founding of Ethology. University of Chicago Press

Tinbergen N. (1963). On aims and methods of ethology. Zeitschrift für Tierpsychologie 20:410-433. 